\title{
Kritik Karl Marx Terhadap Kapitalisme
}

\author{
Musdalifah /90100118006
}

\section{Musdalifahippo093@gmail.com}

Perubahan sosial adalah perubahan yang terjadi dalam masyarakat meliputi perubahan struktur, sistem dan organisasi sosial sebagai akibat adanya modifikasi pola-pola kehidupan manusia, yang dipengaruhi oleh adanya faktor kebutuhan intern dan ekstern masyarakat itu sendiri. Masyarakat sebagai suatu sistem sudah tentu dalam perwujudannya, senantiasa mengalami perubahan yang dapat berupa kemajuan atau kemunduran, luas atau terbatas, cepat atau lambat (Afifuddin, 2015).

Pembangunan ekonomi yang kapitalistik, menurut cara pandang Marxis konvensional, bisa melalui dua jalan. Jalan pertama, yang dianggap ideal adalah jalan dari bawah ditempuh melalui proses pembebasan para borjuasi dari kungkungan kelas-kelas sosial dominan di pedesaan maupun di perkotan. Sedangkan jalan kedua, adalah model Prussia yang bersifat top down. Jalan ini ditempuh ketika tidak terdapat kelas pemilik modal yang cukup kuat yang memaksa negara mengambil alih peran utama dalam pembangunan dart industrialisasi (Hiariej, 2006).

Ernest Mandel dalam buku Bagong Suyanto yang berjudul "Sosiologi Ekonomi:Kapitalisme dan Konsumsi di Era Masyarakat Post Modernisme" membahasa lebih perinci dan mengajukan lima ciri pokok dari ekonomi kapitalisme. Pertama, ditingkat produksi, corak kapitalis adalah produksi komoditas, untuk meraih keuntungan yang sebesarbesarnya. Kedua, produsksi dilandasi kepemilikan pribadi. Ketiga, produksi dioperasinalkan dalam rangka meraih mengusai pasar yang berada dibawah kendali persaingan. Keempat para kapitalis berupaya merauk keuntungan yang sebesar- besarnya dengan cara melakukan. Kelima, Tujuan terakhir dari porduksi adalah akumulasi kapital (Sirajuddin,and Tamsir, 2019).

Melihat sejarahnya, berbicara kapitalisme seolah tak mungkin untuk mengabaikan Weber dan Adam Smith. Kedua nama tersebut akan dikutip dalam menengok sejarah kapitalisme. Menurut Huntington, "ada tesis Weber yang menyatakan bahwa protestanisme mendorong usaha ekonomi, perkembangan borjuasi, kapitalisme, dan kemakmuran ekonomi, sehingga memperlancar munculnya lembaga-lembaga demokrasi”. Sedangkan Fakih menyatakan, Adam Smith merupakan pemikir pertama yang mengembangkan pentingnya 'akumulasi kapital' dalam pengembangan ekonomi. Teori Adam Smith tentang labour theory 
of value itu kemudian menjadi dasar kapitalisme (Kartini et al., 2017).

Sistem ekonomi kapitalis adalah sistem perekonomian yang memberikan kebebasan secara penuh kepada setiap orang untuk melaksanakan kegiatan perekonomian seperti memproduksi barang, menjual barang, menyalurkan barang dan lain sebagainya. Dalam sistem ini pemerintah bisa turut ambil bagian untuk memastikan kelancaran dan keberlangsungan kegiatan perekonomian yang berjalan, tetapi bisa juga pemerintah tidak ikut campur dalam ekonomi. Dalam perekonomian kapitalis setiap warga dapat mengatur nasibnya sendiri sesuai. Namun Karl Marx mengkritik paham terkait dengan sistem kapitalisme.

Karl Marx mempunyai nama lengkap Karl Heinrich Marx. Ia dilahirkan pada tanggal 5 Mei 1818 M di kota Trier-Prusia sebelah perbatasan barat Jerman. Ia dilahirkan ditengahtengah keluarga Yahudi (Kambali, 2020). Bagi Karl Marx, esensi dari sistem kapitalisme adalah pelipat gandaan kapital (uang). Dengan uang para kapitalis membeli tenaga kerja dan mesin produksi untuk menghasilkan komoditas. Setelah komoditas dihasilkan para kapitalis menjualnya lagi untuk mendapatkan uang yang lebih banyak lagi. Sirkulasi pertukaran barang dan perubahan uang menjadi komoditas dan berubah lagi menjadi uang, di kenal dengan pola M - C - M.3 Nilai lebih yang diambil oleh kaum kapitalis dari kaum buruh pada dasarnya adalah sebuah tindakan pencurian terhadap hak-hak kaum buruh yang di sebut Karl Marx sebagai tindakan eksploitasi. Modal atau kapital dapat diibaratkan seperti uang yang dipergunakan untuk memperoleh lebih banyak uang (Kambali, 2020). Modal adalah uang yang tidak digunakan untuk membeli barang-barang kebutuhan ataupun barang-barang yang diinginkan individu. Modal adalah uang yang ditanam supaya tumbuh dan menghasilkan lebih banyak uang (hendrawan, 2014).

Pandangan sistem ekonomi kapitalis mengatakan bahwa menyamakan antara kebutuhan dan keinginan adalah hal yang tidak tepat dan tidak sesuai dengan fakta (Sholahuddin, 2007). Karya-karya awal Marx berbicara mengenai hubungan antara kerja dan hakikat manusia. Marx meyakini bahwa sistem produksi kapitalis membuat kerja manusia menjadi tidak sesuai dengan hakikat kemanusiaannya. Ketidaksesuaian antara hakikat kemanusiaan dan kerja tersbut disebut alienasi (Hendrawan, 2014). Dalam hal ini, manusia yang terlibat dalam proses produksi adalah sebagaimana struktur pengorganisasian sosial produksi yang terdiri atas kaum pemilik modal dan kaum pekerja. Hubungan-hubungan produksi selalu mengambil bentuk hubungan hak milik dalam masyarakat dan hubungan sosial sesuai apa yang telah diatur masyarakat tentang kondisi dan kekuatan produksi serta menyalurkan hasil produksi kepada anggota masyarakat. 


\section{DAFTAR PUSTAKA}

Sirajuddin, dan Tamsir. (2019).Rekonstruksi Konseptual kepemilikan Harta Prespektif Ekonomi Islam (Studi Kritis Kepemilikan Harta Sistem Ekonomi Kapitalisme). Jurnal Laa Maysir, 6(2). hal. 211-225.

Afifuddin. (2015). Pendidikan dengan Pendekatan Marxis-Sosialis. Jurnal Adabiyah, 15(2), hal. 193-207. http://journal.uin-alauddin.ac.id/index.php/adabiyah/article/view/703

Hendrawan, datu. (2014). Alienasi Pekerja Pada Masyarakat Kapital. Jurnal Filsafat, hal. 1333. https://media.neliti.com/media/publications/232226-alienasi-pekerja-padamasyarakat-kapital-5ea7b7db.pdf

Hiariej, E. (2006). Perkembangan Kapitalisme Negara di Indonesia. Jurnal Ilmu Sosial Dan Ilmu Politik, 10(1). hal. 91-120.

Kambali, M. (2020). Pemikiran Karl Marx Tentang Struktur Masyarakat (Dialektika Infrastruktur Dan Suprastruktur). Jurnal Pemikiran Dan Penelitian Ekonomi Islam, 8(2). hlm. 63-80. https://media.neliti.com/media/publications/332489-pemikiran-karl-marxtentang-struktur-mas-fb1b694e.pdf

Kartini, D. S., Mulyawan, R., \& Yuningsih, N. Y. (2017). Kapitalisme Pedesaan Di Kawasan Ekonomi Khusus (Kek) Tanjung Lesung Kabupaten Pandeglang Propinsi Banten. CosmoGov, 3(1). hlm. 55. https://doi.org/10.24198/cosmogov.v3i1.12636

Sholahuddin, M. (2007). Kritik Terhadap Sistem Ekonomisosialis Dan Kapitalis. Jurnal Ekonomi Pembangunan: Kajian Masalah Ekonomi dan Pembangunan, 2 (2). hlm. 193). https://doi.org/10.23917/jep.v2i2.3915 